\title{
Emerging Dialogic Structures in Education Reform: An analysis of Urban Teachers' Online Compositions
}

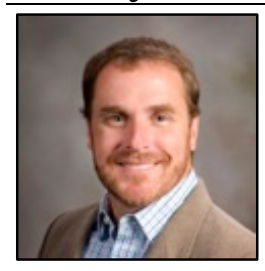

Trevor Thomas Stewart

Virginia Tech, USA

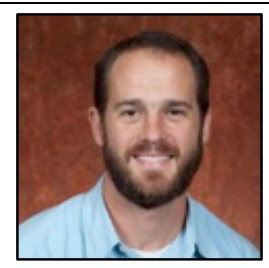

George L. Boggs

Florida State University, USA

\begin{abstract}
This paper contextualizes contemporary urban teachers' online dissent in public discussions of education reform in relation to past educational crisis narratives to interpret recent shifts in the structure of education reform dialogue in the United States. It does so by examining the form and content of compositions in which teachers respond to education reform. The analysis is intended to describe the digitally mediated roles teachers are asserting in a complex public debate over the future of education in the United States. The structure and content of education reform discourse has often cast teachers in static roles, which inhibits their active participation in discussions of educational policy. Using Mikhail Bakhtin's position that language choices serve to stifle and/or reinvigorate dialogue, we examine contributions to online discussions and debate composed ostensibly by urban teachers in response to dominant discourses. The data were analyzed with respect to discursive choices and grouped subsequently as themed arguments and rhetorical moves. We argue that teachers' strategic responses to education reform challenge stifling truisms that seek to suspend discussion of all other factors besides teacher quality. Teachers' critical digital compositions thus re-create critical, multi-voiced conversations in place of monologues about school improvement. The online, public compositions point to the dynamic structure of reform discourse that has the potential to benefit those currently faulted for a variety of social problems. Nurturing and even exploiting the dynamic potential of educational reform discourse can create opportunities for teachers, policymakers, and educational researchers to mutually inform one another's shared interest in educational improvement.
\end{abstract}

Keywords: Education reform; Teacher activism; Dialogism; Teachers as writers; Dissent; Online civic participation

Trevor Thomas Stewart is an Assistant Professor and the Program Leader for English Education at Virginia Tech. His research draws on sociocultural theory and Bakhtin's dialogic framework for language to explore the influences of educational policy and high-stakes testing on English teachers' instructional practices and efforts to bring content into dialogue with students' lives.

George L. Boggs is Assistant Professor in English Education at Florida State University. His research is grounded in sociocultural theory and focuses on literacies that help people think about and engage in communities, particularly 21 st century literacies and authentic writing in and out of school.

Acknowledgements: We would like to acknowledge Bob Fecho for facilitating our inquiry into Bakhtin's work and the lives of teachers; the AERA Writing and Literacies Special Interest Group for encouraging our study of teachers' compositions and offering us a place to develop our ideas; the teachers who are 


\section{Emerging Dialogic Structures in Education Reform Trevor Thomas Stewart, George L. Boggs}

making public advocacy a part of their professional lives; and the editors at Dialogic Pedagogy Journal for their careful feedback and support.

$\cos \cos 80$

In the realm of educational policy debate, teachers often feel powerless and excluded from discussions about how to best approach teaching and learning (Stewart, 2012; Rud, 1993). As education reform directives emanate from centralized education reform sources (e.g. school administrators, district policies, state legislation), contemporary management systems are being applied to the teaching profession (Au, 2011). Our work examines the digital speech being produced in the conflict-laden environment of education reform debates in the United States. In this paper, we focus on teachers' online print compositions to interpret patterns of dissent that suggest the potential for contemporary education reform discourse to admit new voices.

Urban teachers' critical digital compositions regarding education reform exemplify the way Information and Communication Technologies (ICT) are used to critique, interpret, distribute, and comment on a variety of issues (Leu, Kinzer, Coiro, \& Cammack, 2004; Jenkins, Purushotma, Weigel, Clinton, Robison, 2009). Critical digital compositions are reading and composing practices that position people as active agents capable of altering a setting, including human activity, via digital means (Boggs \& Stewart, 2014). Digitally mediated compositions enable teachers to take a more active and prominent role in the discussion of U.S. educational policy. For example, a digital composition published by National Board Certified teacher and blogger Renee Moore (2009) appears on a discussion board extending teacher-activist Anthony Cody's Ed Week blog post, in which he highlighted an Oakland area teacher's education reform concerns. In her comment, Moore problematizes the lack of communication in existing education reform debates:

\footnotetext{
Administrators randomly jumping from one reform idea to another without strategic thinking or teacher input: been there too. Interventions to help disruptive or troubled students--starting with those used by the teacher-should be in place. Suspensions can only be one tool in a plan, not the only tool. What I hear in this story though is a lot of miscommunication or no communication. Not all the students are disruptive; not all the parents show up to fight in public; surely not every administrator in the district is ineffective--so what's the rest of the story?
}

Like Cody, Valerie Strauss (2015) has also used her Washington Post blog to publicize teachers' existing online dissent. As is the case with much User-Generated Content (UGC) online, Strauss and Cody's sites include opportunities for the general public, including teachers like Renee Moore, to engage in digitally produced open debate about education reform.

We seek to describe the dialogic character of teachers' compositions to portray their emerging role in education reform dialogue. This paper considers the changing structure of education reform dialogue by focusing on teachers' rhetoric concerning their professional and civic roles against a backdrop of education reform. We examine teachers' efforts to replace familiar patterns of teachers being spoken for with new ones in which urban teachers' public, online statements demand a more inclusive discussion. To support this work, we offer historical examples of unilateral education reform discourse. The dialogic character is interpreted through thematic, logical dimensions and by the ways speakers manipulate language mechanically to persuasively offer prospective readers valid alternatives to popular messages in education reform. Describing teachers' compositions is vital to understanding the complex democratization of education reform discourse. 


\section{Emerging Dialogic Structures in Education Reform}

Trevor Thomas Stewart, George L. Boggs

\section{Bakhtin and Dialogue Structures}

\section{Participation through Discourses}

Changes in the education reform dialogue might be summed up by simplistically acknowledging the participation of teachers, parents, popular media, and other newcomers to a discourse previously reserved for policy makers and school administrators. Because this participation is occurring in large part through user-generated online media, it is not enough to simply say that changes in the cast of characters struggling over education reform has altered that discourse. A Discourse, in the sociocultural sense of ways of living and organizing social action, (Gee, 2008) includes discourses-patterns of interaction among members of a group. A Discourse changes when its component practices, such as its discourses, are challenged and altered. These challenges often originate in evolving membership, in community responses to economic pressures, and in the process of appropriating new tools (Gee, Hull, \& Lankshear, 1996). The discursive challenges and changes we are discussing in this paper are occurring through new forms of participation manifested in strategic manipulation of language online situated in relation to education reform discourses governed by neoliberal economic policies (Au, 2011).

An awareness of the potential of new literacies and user-generated content to carry out new purposes and actively and intentionally modify recurring dialogue flows from the notion of speech as inherently dialogic and alive. Bakhtin (1981) was interested in language's potential to overcome the unitary tendency of every speech pattern in a community (i.e. profession). He argued that "language is stratified... into languages that are socio-ideological" (p. 199) and can function restrictively as "a sealedoff and impermeable monoglossia" (Bakhtin, 1986, p. 61). We conceptualize education reform discourse as a stratified language occurring in a social and historical context that excludes certain members in part by presenting teachers as culpable for school failure (Hattie, 2009, 2011; Karp, 2012). Bakhtin (1981) saw centrifugal forces in language eroding the centripetal, specifically weakening the seals limiting who can participate and who can produce knowledge within certain speech genres. We draw on Bakhtin's work to illustrate how language in use-even stratified language-provides conditions for multiple voices to engage in dialogue. In the case of the education reform speech genre, teachers' compositions are producing fractures in the barriers to participation. We see teachers' compositions as means of superseding the stratified language of education reform and restricted access to participation in policy dialogue.

\section{Addressivity in Stratified Language}

We theorize language, despite its stratification, as exhibiting both centrifugal and centripetal forces (Bakhtin, 1981). Live speech occurs in strategic relation to an audience. Utterances are crafted with every word "born in a dialogue as a living rejoinder within it" (p. 279). The concept of addressivity in Bakhtin's (1986) work positions living speech as a form of strategic social action because "from the very beginning, the utterance is constructed while taking into account possible responsive reactions" (p. 94). Addressivity calls attention to compositions as interpersonal struggles: Every statement responds to prior utterances, anticipates future utterances, and enacts a speech plan, which seeks to "take into account the apperceptive background of the addressee's perception" (Bakhtin, 1986, p. 95) of the utterance. As Bakhtin noted, accounting for an addressee's potential response involves attention to class structure and power dynamics when speakers confront restricted speech genres. A speaker's semantic choices may be interrogated as stratagems and investigated as a means of locating and understanding the rhetorical choices employed in the socio-ideological structure of stratified language. Speech represents speakers' planning and efforts to control others' responses, or as Bakhtin (1981) put it, "to infect with its own intention" (p. 90) and impose sematic nuances designed to elicit particular responses from potential 


\section{Emerging Dialogic Structures in Education Reform}

Trevor Thomas Stewart, George L. Boggs

addressees. This process of evoking responses depends upon people's ability to manipulate language to impose and undo restrictions on meaning.

\section{New Literacies and Social Action}

Examining stratified communication settings, such as education reform debates, where some members' opportunities for response have been restricted, involves recognizing power dynamics and speech plans constructed to modify existing linguistic conditions-in other words-speakers' efforts to make room for themselves to speak and be heard. In order to do so, speakers are drawing on the centrifugal forces of language to "wrest new answers" (Bakhtin, 1981, p. 346) from prior utterances as they construct utterances in anticipation of possible responses.

Bakhtin's (1986) account of language as an interindividual struggle is anchored in the religious, social, and technological upheaval known collectively as the Renaissance. Religious non-conformism, inexpensive printing, and the shift toward social contracts from the Divine Right of Kings exemplify the "rebirth" of human civilization through profound revision of the speech events that order human life. Bakhtin sought to explain the production of texts as means of organizing (re-organizing) the world. This explanatory effort is particularly relevant in the Digital Age. Internet users have almost limitless capacity to contest not only religious and political scripts, but create their own at very little cost. Brandt (2014) points to ubiquitous digital composition in everyday personal civic and economic life as an epochal shift towards writing, as opposed to reading, as the foundational literacy practice of myriad discourses. Digital composition on the World Wide Web super-affords the text-producing work Bakhtin associated with Renaissance upheaval. Social networks, hyperlinks, cutting-and-pasting, memes, instantaneous messaging, and multigenre texts enable users to find new religions, press for legal protection, publish unfathomable oceans of text for pennies, and strip sovereign governments of their capacity to rule. With digital composition as the new normal for personal, civic, and economic life, resistance to stratified language and the process of dragging previous utterances into live speech very likely involves screens and keystrokes.

\section{Education Reform and the Role of Teachers}

Long before Internet and Communication Technologies enabled civic action as they do today, education reform has served centralized political goals. As far back as Aristotle's Politics, schools have been presented as obligated to protect the state by replicating the actions, knowledge, and relationships that are the foundation of the state. The classical notion that schools should prevent social problems has morphed over time into a kind of trap that blames schools for longstanding social problems. In the Kerner Report following urban unrest in the mid-1960s, schools were left holding the bag for "two societies, one black, one white-separate and unequal" $(1968$, p. 1). With the launch of Sputnik and Cold War fears that U.S. global preeminence was waning, A Nation at Risk (1983) dramatized a crisis in which schools were making the nation vulnerable.

Decades of neoliberal reforms in the U.S. have since privileged numerous reform measures, such as high-stakes testing, as means of regulating teacher performance (Goldstein, 2014; Kohn, 2011; Ravitch, 2013). The blame for the perceived crisis is being laid at the feet of teachers. As the rhetoric has intensified to portray teachers as the problem plaguing U.S. schools, teachers have employed critical digital literacies to disrupt and challenge prevailing narratives (Boggs \& Stewart, 2014) and materially alter the structure of education reform debate. 


\section{Emerging Dialogic Structures in Education Reform}

Trevor Thomas Stewart, George L. Boggs

\section{Persuasive Language, The Social World, and Education Reform}

The language of education reform draws upon a social history linking the problems of society and the mandate that schools should function to fix those problems. From Aristotle to the Kerner Commission, schools have been assigned the civic role of preserving the state and curing societal problems. This perspective has made it easy for education reform rhetoric to frame teachers as culpable for persistent social problems. In this way, schools become theatres whose stages are populated by static characters who only have one civic role to play: teaching the students in their charge-while magically banishing society's problems in the process. In this static role, teachers are not expected to take civic action divergent from that prescribed to them by virtue of their institutionally assigned role. The notion of teacher accountability drives the rhetoric in the education reform debate. The rhetoric of dominant school reform narratives locates teachers as the most important factor in school effectiveness (Carnegie, 2007). However, this fixation on teachers as the key to school improvement places teachers in what has been described as a double bind (Achinstein \& Ogawa, 2012). They are relegated to acting only in the context of their classrooms within traditional dialogue structures yet held responsible for pervasive problems.

In the context of education reform, crisis narratives dramatize the need for action oftentimes by framing what is happening metaphorically. The Kerner Commission report of the 1960s presented a crisis narrative couched in sociopolitical catastrophe, making analogies and metaphors that connect to negative, dangerous, and unwanted social memories. Its rationale for educational reform confronts readers with a picture of a segregated, economically stagnant United States almost exactly 100 years after the bloodiest war in U.S. history was waged to preserve unity. In hopes for social unity, the Kerner Commission Report (1968) threatens "polarization of the American community" (p. 1) and positions artificially integrated schools as a straightforward solution. The Commission positioned schools as responsible for urban unrest because they have failed to produce a nation united.

In 1983, A Nation at Risk repeated the school failure line, this time blaming schools for the loss of "once unchallenged preeminence in commerce, industry, science, and technological innovation" (p. 1). From the opening pages, the document enacts a speech plan that seeks to incite fear by creating the sense that the nation is under attack.

\footnotetext{
If an unfriendly foreign power had attempted to impose on America the mediocre educational performance that exists today, we might well have viewed it as an act of war. As it stands, we have allowed this to happen to ourselves. We have even squandered the gains in student achievement made in the wake of the Sputnik challenge (p. 3).
}

Acts of war and educational disarmament metaphorically underwrite educational reform as a Cold War necessity. This Manufactured Crisis (Berliner \& Biddle, 1995) encouraged Americans to seek security through seemingly straightforward measurements of student achievement.

For a nation that had followed with great anxiety the price of oil and value of U.S. enterprises in the midst of the oil crisis of the late 1970s, school failure could be understood as placing the nation at risk and strictly numerical assessment could be understood as an absolute necessity. The report hailed standardized testing data as "rocks of stability in a sea of unanchored opinions" (Berliner \& Biddle, 1995, p. 14). Evoking a stock's potential for losing value, standardized testing data were used to sound the alarm and rally the reform movement to stop what appeared to be steep declines in student achievement. This line of rhetoric cleared the way for the No Child Left Behind Act (NCLB) to be passed in 2001. The logic asserted by official reformers was that education could be most effectively improved by creating consequences for schools' collective scores on standardized tests (Nichols \& Berliner, 2007). Current 


\section{Emerging Dialogic Structures in Education Reform}

Trevor Thomas Stewart, George L. Boggs

initiatives extend those consequences to individual teachers. This can be clearly in seen the use of ValueAdded Models (VAM) that evaluate teachers based on the test scores of their students. The statistical validity problems associated with VAM (Rush \& Scherff, 2015) punctuate a long history of political propaganda that position schools and teachers as the saviors of society.

\section{Critical Digital Compositions and Teacher Voice}

Teachers are using Information and Communication Technologies to drag stratified language of education reform into live speech, adding their own perspectives and building new networks to challenge reform narratives and question the reform narratives that have emerged as simplistic solutions to complex problems. With a perspective theoretically linking the crafting of online statements to quality of the discursive process employed, we asked how critical digital compositions facilitate teachers' efforts to challenge the status quo and assert themselves in educational policy debates? We used the following subquestions:

1) What arguments characterizing urban education reform appear in online posts purporting to represent the perspectives of urban teachers?

2) How does the construction or presentation of these arguments seek to manage or evoke responses among potential addressees?

3) What goals are evident in these speech plans?

\section{Methodology}

In order to interpret possible changes in the structure of dialogue, we focused on how the arguments and rhetorical moves contained in the teachers' compositions suggest divergent dialogue structure. Bakhtin's (1981) idea of "socially typifying languages" (p. 290) points to a linguistic phenomenon in which interactions within a particular group may be seen as a representation of the group itself. Ethnography of Communication (EOC) (Hymes, 1964; Saville-Troike, 2003) is a socio-linguistic methodology that draws attention to patterned language use in speech communities. EOC is unique in that it takes acts of speech as the starting point for understanding how society is organized. In EOC, acts of speech rather than observed behavior or social relationships are the vehicle for making an account of a community. Patterns occur in communication situations among members of speech communities in ways that serve to regulate who speaks when and how. This ethnographic perspective asserts that what is said and who says what in such situations has much to teach us about how human life is ordered through language in particular contexts. Patterned speech that diverges from established discourses can thus suggest altered social settings. This process of interaction among languages and social groups is at the heart of Bakhtin's theory of language. We employed theoretical and methodological tools that would facilitate examination of intersecting discourses.

\section{Methods}

We see this methodological perspective as important for helping us apply Bakhtin's (1981) theory of language to develop a method for collecting data in an internet communication setting. Specifically, our methods were designed to capture empirically the restructuring of education reform discussions. Our method consisted of collecting and curating what urban teachers are saying online about urban education reform, making sense of the variety and commonalities among their compositions, and interpreting them in socio-historical and sociolinguistic contexts. 


\section{Emerging Dialogic Structures in Education Reform \\ Trevor Thomas Stewart, George L. Boggs}

\section{Data Collection}

U.S. teachers' civic action has gained notoriety and prominence in the public eye, from large scale teacher strikes and other actions in Chicago, Madison, and Detroit of the mid-western U.S. to academic discussions of teachers' online grassroots activism (Heron-Hruby \& Landon-Hays, 2014). As the concerns of teachers and parents became pervasive on social media, we grew interested in teachers' public responses to education reform rhetoric. With a sense of disproportional effects of education reform on urban settings, we were especially interested in how urban teachers were speaking out. Our goal was to examine teachers' efforts to engage in public dissent by reading their compositions occurring in public dialogue settings not mediated by an interview setting or a discussion forum set up specifically for the purposes of a research study. Drawing on the methods we employed in an earlier report related to teachers' rights to participate in the organization of urban spaces (Boggs \& Stewart, in press), we collected teachers' public digital compositions about educational reform as elements of a highly politicized struggle over school and teacher quality. Urban teachers receive significant blame for school failure (Anyon, 2014; DeMatthews \& Mawhinney, 2014; Warren, 2005); therefore it is important to listen to the efforts of those teachers to respond to criticism being leveled at them.

Our interest in the potential for critical digital compositions to facilitate the teachers' efforts to participate in the education reform speech community (Boggs \& Stewart, 2014) led us to focus on published urban teachers' compositions related to neoliberal reform policies and practices (e.g. highstakes testing). We employed a graduate student who is a practicing teacher to collect the teachers' compositions using focused search terms (i.e., urban teacher blog, blog on teacher evaluations, why inner-city school teachers have it harder, teacher evaluations aren't fair). We stipulated that the data should be gathered from internet platforms in which urban teachers' compositions addressed education reform. By collecting selections from already existing compositions, we were able to capture teachers' self-motivated compositions instead of responses produced specifically for a research study.

This process involved using search engines to access a variety of urban teachers' online, public statements from online public discussion spaces: individual blogs, blogs that feature multiple contributors, blog comment sections, activist networks, and popular news outlets including their discussion sections such as TIME Magazine and EdWeek. Statements crafted by those who we believed presented themselves as urban teachers were compiled in a single table containing excerpts and hyperlinks to source texts and contexts online. We then read the text selections in their published contexts (e.g. blog posts; popular media articles).

\section{Data Analysis}

We reviewed the data individually and used thematic analysis (Maxwell, 2005) to identify trends in the urban teachers' compositions and code the data. We sampled cohesive units of speech mindful of Bakhtin's (1986) stipulation that "concrete utterances" have the possibility of response yet vary by "their length, their content, and their rhetorical structure" (p. 71). We sought to identify salient themes in these cogent blocks of online published compositions to understand the kinds of potential for response (i.e. understanding and/or action) teachers were producing. In order to foster awareness of the subjectivities influencing our responses, we worked individually as we organized the data into broad, theoretical categories for further analysis.

The opportunity to describe the phenomenon of teachers' critical digital compositions inspired multiple positions from which to read and respond to teachers' words. We each created lists of individual codes that helped organize the rhetorical work we saw occurring within these compositions. Once we 


\section{Emerging Dialogic Structures in Education Reform}

Trevor Thomas Stewart, George L. Boggs

completed our individual reading and categorizing of the data, we engaged in a dialogue focused on reflective comparison of our lists of tentative codes to clarify areas of agreement, reconcile areas of departure, and attend to our positionalities as readers. We affirm that our apperceptive backgrounds as potential addressees mediated our "active responsive understanding" (Bakhtin, 1986, p. 96) of each composition we read. We sought to reconcile our positions as teachers and teacher advocates with our postionalities as teacher educators and researchers. Our efforts to negotiate this complex collision of ways of being and seeing the world were facilitated by our dialogue in which we interrogated and explored these positionalities. To illustrate one tense moment in this dialogue, one of us argued that the other was funneling a variety issues affecting urban education into a single pool defined in the end by their relationship to poverty. He had connected phrases in one composition lamenting a school "filled with student apathy" and "lack of parent involvement" to issues of poverty and inequality because of his experiences teaching in a school district with a high percentage of low-income families where he experienced these issues as interrelated. Without discounting the interrelationship among issues teachers had raised and poverty, the conversation evolved toward awareness of the need to describe teachers' compositions in ways that maximize face validity and the likelihood that another reader might use similar language to describe the rhetorical work occurring within and across compositions. We wanted to organize the data in ways that did not foreclose on a reader's ability to see the complexities contained in the teachers' compositions. Our dialogue resulted in the creation of codes that function as conceptual interpretations of the data and, in conjunction with diverse sampling of teachers' compositions included throughout the manuscript, allowed the compositions to speak for themselves. Our codes reflect the influence of our own positionalities and Bakhtin's influence on our reading of the teachers' compositions.

The stratification of language that Bakhtin (1981) described guided our analysis of the data. He argued that elements of an author's "semantic and expressive intentions are refracted within" (p. 311) different linguistic planes. Our analysis examined three dimensions of the teachers' compositions to facilitate our understanding of the intersection of linguistic resources contained in teachers' compositions. We called those dimensions: Themed Arguments, Rhetorical Moves, and Word Choice.

We offer this excerpt from one teacher's composition below to demonstrate the way the first two dimensions (Themed Arguments and Rhetorical Moves were used to analyze and describe teachers' rhetorical work:

They are so angry and disempowered and cynical. They never got the training they needed, they don't get the on-going support they need, and the pressures and demands of their daily jobs are overwhelming. I also work with and try to support administrators who never got the training or support they needed and who are overwhelmed by the incredible pressures of NCLB.

The first dimension these compositions included was logical or argumentative focus, which we called Themed Arguments. In the excerpt above we used the code Labor Issues to identify the excerpt's argumentative focus (see Fig. 1), which lamented a lack of support for teachers. The other Themed Arguments codes we utilized to describe and organize teachers' compositions were Failed Mandate, Neoliberal Agenda, Testing, and Diversity Issues.

The second dimension (Rhetorical Moves) had to do with the rhetorical effect of the semantic and verbal choices occurring in the compositions in a complimentary relationship with the argumentative focus. In the composition excerpt example above, the teacher knew those whom she referred to as "they," and she positioned herself as a local authority to comment on the clash between insider and outsider interests. We assigned the second dimension code Insider vs. Outsider Status as a Rhetorical Move 
occurring within this selection based the writer's juxtaposition of local people's work with external "pressures" (see Fig. 1). The other Rhetorical Move codes we utilized were Intertextuality, Text Features, Critiquing Narrative, Personal Anecdote/Indirect Speech, Historicizing, Rhetorical Question, and Gesture to Authority. The criteria for the application of all of the codes reflective of the first two dimensions are summarized in Figure 1 (see below).

Figure 1. Coding categories and criteria

\begin{tabular}{|c|c|}
\hline $\begin{array}{l}\text { Themed Arguments } \\
\text { Codes }\end{array}$ & Criteria (Argument asserts that...) \\
\hline Failed Mandate & $\begin{array}{l}\text { Mismanagement or conflicts of interest have undermined } \\
\text { established authorities' right to govern policy and practice. }\end{array}$ \\
\hline Neoliberal Agenda & $\begin{array}{l}\text { State-sponsored contraction of public services accommodates } \\
\text { private capital development. }\end{array}$ \\
\hline Testing & $\begin{array}{l}\text { Inappropriate shifts in curriculum toward test preparation, } \\
\text { standardization, and measurement of students impede teachers' } \\
\text { work. }\end{array}$ \\
\hline Labor Issues & $\begin{array}{l}\text { Local school and district leadership distracts teachers from doing } \\
\text { their jobs effectively. }\end{array}$ \\
\hline Diversity Issues & $\begin{array}{l}\text { Students in urban and other settings face many challenges that } \\
\text { teachers must understand and address; failure to do so results in } \\
\text { ineffective education. }\end{array}$ \\
\hline $\begin{array}{l}\text { Rhetorical Move } \\
\text { Codes }\end{array}$ & Criteria \\
\hline Intertextuality & Explicitly includes or references other texts. \\
\hline $\begin{array}{l}\text { Insider vs. } \\
\text { Outsider Status }\end{array}$ & $\begin{array}{l}\text { Imputes or denies credibility of an argument or speaker based on } \\
\text { their position within or outside urban or other school. }\end{array}$ \\
\hline Text Features & $\begin{array}{l}\text { Includes hyperlinks, underlining, boldface type, non-grammatical } \\
\text { punctuation. }\end{array}$ \\
\hline Critiquing Narrative & $\begin{array}{l}\text { Explicitly acknowledges, through references to familiar language, } \\
\text { spokespersons, or other metonyms, a popular or established } \\
\text { message about teachers or education reform. }\end{array}$ \\
\hline $\begin{array}{l}\text { Personal Anecdote/ } \\
\text { Indirect Speech }\end{array}$ & $\begin{array}{l}\text { Elaborates or contests an argument through the use of personal } \\
\text { testimony or by giving voice to purported colleagues' words or } \\
\text { stories. }\end{array}$ \\
\hline Historicizing & $\begin{array}{l}\text { Purports to place a situation in historical context, referring explicitly } \\
\text { to historical events or settings (e.g., segregation, Civil Rights } \\
\text { Movement). }\end{array}$ \\
\hline Rhetorical Question & $\begin{array}{l}\text { Includes a question with an expected answer that aligns with an } \\
\text { argument put forward in the composition. }\end{array}$ \\
\hline Gesture to Authority & Cites purportedly authoritative or reliable sources to bolster a claim. \\
\hline
\end{tabular}

Word choice. Assessing these first two dimensions helped us understand and describe teachers' contributions to education reform dialogue. As we processed that data, we read, in these compositions, criticisms of the dialogue structure. Some of these criticisms are captured in the Themed Arguments and Rhetorical Move codes, such as Failed Mandate, Neoliberal Agenda, and Insider vs Outsider Status. Our interest in the strategic selection of language to evoke audience responses drew our attention to word choices occurring as a feature of teachers' argumentative and rhetorical work. Teachers' efforts to protest both the problems with education reform itself and the problematic structure of education reform dialogue relied on the use of socio-culturally charged language. Word Choice draws attention to a third interrelated dimension of teachers' online speech where they were "making use of words that are already populated 


\section{Emerging Dialogic Structures in Education Reform} Trevor Thomas Stewart, George L. Boggs

with the social intentions of others" (Bakhtin, 1981, p. 300) to serve their own speech plans. We examined word choices already coded in the Themed Arguments and Rhetorical Move dimensions in an effort to triangulate possible or prospective efforts to restructure education reform debate. We paid special attention to teachers' word choices directed at the debate itself.

To illustrate the importance of word choice in teachers' dissent, we return to the teacher's composition used to illustrate Themed Arguments and Rhetorical Moves:

\footnotetext{
They are so angry and disempowered and cynical. They never got the training they needed, they don't get the on-going support they need, and the pressures and demands of their daily jobs are overwhelming. I also work with and try to support administrators who never got the training or support they needed and who are overwhelmed by the incredible pressures of NCLB (emphasis added).
}

In the excerpt above, we highlight teacher's selection of words called upon to help her express her criticism of failures to communicate effectively with teachers. Analysis of word choice can help connect an understanding of teachers' dissent with their critiques of the structure of education reform debate.

\section{Findings}

In the following sections, we describe how urban teachers' critical digital compositions offer multiple points of connection for readers to participate in a public examination of the issues facing schools and, especially, of the undemocratic approach characterizing much contemporary reform. These compositions point to issues and concepts that the teachers see as missing in the dominant narratives. First, we examine the Themed Arguments contained in the compositions. Second, we describe the Rhetorical Moves that facilitate teachers' efforts to participate in the education reform dialogue and deflect the blame for school failure that has been laid at their feet. Third, we examine the word choices directed at critiquing and altering education reform dialogue.

\section{Themed Arguments}

We paid particular attention to the logical, argumentative dimension of teachers' compositions because the dialogue structure we seek to understand relies on rational propositions framing teachers as culpable for school failure (Hattie, 2011). The use of arguments that offer alternative explanations for school failure points to a creative effort to re-present the education reform dialogue in which previously urban teachers had been tried, convicted, and sentenced in absentia. The argumentative dimension undermines the dominant logical premise of teachers as culpable for school failure. The teachers' compositions represent a kind of appeals process or retrial, in which new evidence is submitted, alternative explanations offered, and, most importantly, a self-defense is offered. Of 65 published online statements by internet users identifiable as distinct urban teachers discussing education reform, 60 included one or more prototypical arguments that deflect blame from teachers for the problems attributed to education. An abbreviated table of compositions grouped by argument theme is included (see Appendix).

Counter claims using socioeconomic arguments were a prominent feature of the Themed Arguments category in teachers' compositions. We categorized these argumentative constructs using the label Diversity Issues to organize elements of teachers' compositions that pointed to issues related to socioeconomic inequality (see Fig. 1 above). Across the data set, teachers argued that students' lived experiences_and especially the lived experiences of students living in poverty-must be part of the 


\section{Emerging Dialogic Structures in Education Reform} Trevor Thomas Stewart, George L. Boggs

discussion of educational reform. For example, one teacher pointed to a key flaw in the education reform debate by saying:

If you claim you're interested in Education Reform but you're not addressing child poverty, then you're just blowing smoke. Poverty is the biggest problem facing public education, and almost no one is talking about it.

The category Diversity Issues especially captures arguments in which teachers deflect blame by arguing that education reform ignores the reality that the children and families they work with are not white, middle class speakers of standard English who have equitable access to the secondary Discourses (Gee, 2008) of schools and other professional communities.

Similar issues are incorporated across Themed Arguments categories. One teacher's composition uses Diversity Issues as she presents "Poor and low-income children" as targets of a fundamentally unfair Testing regime, in which a system designed to sort by merit actually sorts by socioeconomic status. Another composition discusses Diversity Issues as a supporting feature of an argument that charges those in positions of power with a Failed Mandate, in which those who had been invested with the responsibility to safeguard the welfare of children had exploited those in their care. She wrote:

\footnotetext{
[New Jersey Governor Chris] Christie, like every other Republican governor, is scamming the middle-\& uppermiddle-class taxpayers with the promise of lowering their taxes by privatizing public education for the poor, while raking in campaign monies from for-profit education corporations.
}

The alleged use of public office for 'scamming' people evoked this theme of a Failed Mandate. However, the means of exploitation (privatizing) was specifically aligned with other criticisms of economic theories informing both education reform and political maneuvering, which we grouped under the heading Neoliberal Agenda.

The data include many compositions that construct blame-deflecting arguments without reference to students living in poverty. With so many compositions couching their arguments responding to educational reform in terms related to poverty, alternative approaches stand out. One composition we coded under the theme Failed Mandate sought to crack the code of education reform language and sought to juxtapose true from false reforms:

It is easy to distinguish Education Reform and Education Reformers from education reform and people working to reform education. One serves the Reformers and the other serves the students and the community.

While its thematic orientation places it among Failed Mandate compositions, at greater magnification this statement critiques reform language and thinking, offering a fascinating shibboleth that purports to reveal reformers' allegiance:

The first are top-down, include the words "for all students", and are interested in teacher quality. The latter are bottom-up, include the words "for each student", and are interested in quality teaching. One gives more authority to the management and executive class without any accountability, the other empowers teachers and students.

In this statement, the teacher is separating the sheep from the wolves and making it very clear that she does not believe that reformers have students' or teachers' best interests in mind. She concretely 


\section{Emerging Dialogic Structures in Education Reform Trevor Thomas Stewart, George L. Boggs}

illustrates what we coded as a Failed Mandate argument by treating language and the management of the teaching profession as inseparable and mutually constituting one another.

We found a similar pattern in compositions coded Neoliberal Agenda, where teachers critically recontextualized reform language and sought to expose its flaws. In the following composition, one can see the teacher drawing on historical context to critique the neoliberal agenda:

These perspectives sound eerily similar to the countless failed "urban renewal" projects done in cities over the past 60 years-technocrats wanting to demolish what exists and instill their unproven vision of what is best instead of engaging with the people who are already there.

Such compositions critically positioned the language of education reform itself as a means of raising readers' consciousness of educational reform as fundamentally flawed impositions. These critical and resistant readings of education reform texts dismantle monologues seeking to exclude teachers' voices.

Numerous such arguments freeze (Alinsky, 1971) reform rhetoric that seeks to proceed on the basis that teachers must bear responsibility for a range of social problems. Online argumentation affords teachers an opportunity to turn back the clock, contest the often-used blame rhetoric, and appeal to a broad, popular audience. We see consistent evidence of teachers' argumentative efforts to question reform narratives that position teachers as the main cause of school failure and supply counter narratives.

\section{Rhetorical Moves}

Strategically and mechanically, the Rhetorical Moves in the compositions serve a multitude of roles. Several codes for Rhetorical Moves, such as Text features, index verbal and syntactical choices geared toward adding emphasis and directing readers' attention in general. Other Rhetorical MovesHyperlink, Rhetorical Question, Intertextuality, Critiquing Narrative, and Insider vs. Outsider Statusfunction differently by juxtaposing past and present compositions (see Fig. 1). In the following subsections, we describe the Rhetorical Moves we assigned to the data and use examples from the compositions to show how these Rhetorical Moves help teachers assert their a place in the conversation.

Insider vs. Outsider. To illustrate the role of Rhetorical Moves in re-presenting education reform dialogue, the following composition was coded rhetorically as an invocation of insider status: "I challenge anyone to spend one week in an inner city school to see what the reality is because lawmakers and decision makers are out of touch." We regard the teacher's challenge as a strategic move to validate her prospective contributions to one or more speech events she views as fundamentally flawed. She positions lawmakers and decision makers as "out of touch" because they lack insider knowledge. Another composition exemplifies the way insider status levels an attack on dominant patterns in education reform: "Few people outside of schools understand exactly how destructive these changes are." Numerous compositions invoked insider/outsider rhetoric, conveying a sense that reform that does not grow out of conversations with teachers is part of the problem, not the simple solution.

Critiquing the Narrative. To further illustrate the role of Rhetorical Moves in dragging prior speech events back into living discussion, we discuss examples of compositions coded as Critiquing the Narrative. While working in tandem with explicit intertextual linkages, these compositions often relied heavily upon the content and structure of existing narratives as they sought to rob those narratives of their power. Compositions coded as Critiquing the Narrative strategically re-presented parts of education reform debate only to scorn them by pointing out their narrowness, naïveté, or misappropriation. "No matter what measure of "quality' you look at," wrote one teacher, "poor and minority students-and not 


\section{Emerging Dialogic Structures in Education Reform}

Trevor Thomas Stewart, George L. Boggs

just those in inner-city schools-are much less likely to be assigned better-qualified and more-effective teachers." This act of objectifying and interrogating existing discourse-a fundamental feature of legal proceedings-is ubiquitous in the data. The phrase "junk science," appears in one composition an aggressive assault on the validity of the teacher quality reform narrative. It is hyperlinked in the sentence: "Value-Added Measures, as these are often called, have been labeled junk science by national statistical organizations." The link leads the reader to an article attacking the validity of Value Added Measures. The composition has indirect speech ("has been labeled") and a bandwagon appeal in its arsenal among its tactics, yet we find the effort to call up and contest existing narratives particularly important in terms of the struggle over who controls teachers' voices. These efforts bring previous utterances into live speech and call upon the centrifugal forces of language to wrest new meaning and elicit desired responses (Bakhtin, 1981).

\section{Word Choice and the Structure of the Debate}

Our analysis of the Themed Arguments and Rhetorical Moves dimensions of the teachers' compositions provided answers to the research questions we asked. We were able to see what arguments appeared, how they were presented, and, in part, what goals were reflected in the teachers' compositions. The teachers' counter claims were designed to complicate the naïve blame game. Word choices throughout the compositions point to teachers' awareness that part of their response to education reform needed to include a challenge to the way education reform discussions occur. This thread was present in both the Themed Arguments and the Rhetorical Moves dimensions, and it drew our attention to a particular goal shared widely across the data set where word choices in urban teachers' compositions challenged the structure of education reform dialogue. It must be said that teachers' work in publishing the compositions we collected as well as many others we did not collect constitutes a dramatic challenge to the way education reform is discussed and produced. They are arguing implicitly for a place at the table by publishing their own viewpoints. Words choices within these compositions elaborate on and inform a trenchant critique of the education reform debate. Using what Gee (2008) termed "mushfake Discourse" (p. 251) to describe "evading the gatekeeping efforts of elites in our society" (p. 251), urban teachers selected words that highlighted their exclusion and presented arguments for their future inclusion in education reform debates.

The teachers' compositions strategically represented education reform speech as flawed due to the form of discussion (or lack of discussion) it conveyed. Across the data, teachers chose words such as "recipe for mediocrity and bias," "promise," "deficit discourse," and "unproven vision" to note restricted, monologic speech encountered in education reform debates. These word choices contest the foreclosure of dialogue.

Teachers further upset one-sided dialogue structure with a variety of verbal constructions in their compositions. Reformers are challenged to incorporate discussions of poverty as a feature of the complex causes of social problems as discussed above as an example of Diversity Issues (see above). Other teachers degraded the authority of reform language by imputing a kind of recycling of misguided policies, as in the teacher's composition discussed earlier to critique the Neoliberal Agenda (see p.13 above, "eerily similar"). Many compositions asserted a destructive combination of dictatorial leadership and incompetence, as illustrated in the use of the following phrases:

- "wants total power"

- "system... designed to hold them back"

- "decision makers out of touch"

- "control over our...children" 


\section{Emerging Dialogic Structures in Education Reform} Trevor Thomas Stewart, George L. Boggs

- "instill their unproven vision"

- " $\quad$ think they know all when they know nothing" (see Appendix).

These phrases do more than merely contest reformers' claims or the consequences reform may have on schools and teachers. Indeed, such phrases assert an active role for teachers and others as eyewitnesses of education. In the composition below, one can see the groundswell of desire for participation coupled with layered critiques:

\footnotetext{
A growing number of parents, school boards, teachers and civil rights organizations are beginning to question the fairness of our overreliance on standardized tests and recently over 300 groups, including the NAACP Legal Defense Fund, signed a petition to ask congress to ban the use of such tests.
}

These semantic choices were strategic in arguing that the dialogue structure has been changing to represent the interests of a broader group of stakeholders.

Across the data, the teachers used layered rhetorical tools that work in concert to redirect negative attention focused on urban education. We do not suggest that teachers are now speaking with a collective voice to say the same things. However, information and communication technologies and usergenerated content tools facilitate the exchange of diverse ideas, ideological stances, and rhetorical practices. The data set did not suggest one ideological orientation. Our claim is that Themed Arguments, Rhetorical Moves, and word choices directed at the structure of education reform debates represent teachers as active agents in a dialogue that they feel qualified and compelled to join. In the following sections, we discuss the significance of teachers' efforts to discount the blame narrative leveled at them.

\section{Discussion}

Examples of changes in the structure of large-scale social dialogues can be seen throughout recorded history. The rediscovery of classical Greek texts in Europe via Islamic civilizations at the turn of the $1^{\text {st }}$ millennium is an important feature of any study of European civilization. Access to the work of Aristotle and others afforded European participation in discussions of science and philosophy. Mass production of such texts fueled significant increases in who could participate in discipline-specific discussions long confined to elite scholars. The most relevant example of change in large-scale social dialogue to our discussion would be the formation and growth of teachers' unions. Unions exert power in part in relation to the size of their membership. Unions purport to represent the interests of their membership, unifying members to assert collective power. In so doing they speak for individual teachers who ostensibly would have great difficulty being 'heard.' In the turmoil of the 1960s, in which the Kerner Commission Report (1968) blamed schools and teachers for contributing to "racial isolation" (p. 22) membership in the smaller of the two major national U.S. unions rose from 65,000 to over 400,000 (American Federation of Teachers, 2004).

Public discussion of education reform follows the pattern Bakhtin (1986) set out for stratified languages where "alongside verbal-ideological centralization and unification, the uninterrupted processes of decentralization and disunification go forward" (p. 272). Such changes in dialogue structure may be and have been interpreted in a variety of ways. We do not see emerging dialogue structures or teachers' active participation as indicative of neat battles between good and evil, freedom and oppression, or democracy and totalitarianism. Graff (1987) and Gee (2014) recognize to the sociopolitical complexities of literacy in their discussions of Sweden's Church Law of 1686, which legally mandated that all people, irrespective of class or gender, "learn to read and see with their own eyes what God bids and commands in His Holy Word" (cited in Graff 1987, p. 150). In Sweden, the people might well have been reading and seeing precisely what those in power wanted them to see; however, the ability to read and see on one's 


\section{Emerging Dialogic Structures in Education Reform}

Trevor Thomas Stewart, George L. Boggs

own opens the door for interpretation as myriad readers join the dialogue. When people enter a public discussion whether through acquiring print literacy or composing dissent online, unilateral discourse becomes harder to enforce.

\section{Teachers' Compositions \& Restructuring Dialogue}

While acquisition of forms of literacy judged to be powerful in a given time and place has often been treated as a means of safeguarding civilization, democracy, and all kinds of notions of progress (Graff, 1979), our work focused on the lived experience of literacy in the context of the education reform speech community. Ultimately, changes in how we communicate can reflect radical changes in human civilization. However, we see these phenomena as more complicated than traditional myths of literacy would have us believe. We noticed rhetorical similarities in union and grassroots teacher activism: Differences are likely to be constructed as conflicts and confrontations, for example. The decentralized, varied, and personal flavor of teachers' online compositions leads us to ask what differences matter in teachers' processes of reaching consensus in this evolving dialogue.

The characteristics of the union's dialogic process seem to favor unity among teachers in anticipation of conflict-laden negotiations with distinct opponents. In reference to union representation of teachers' interests, we wonder at the iterative process of teachers' online activism and the role of the internet in building consensus, destroying consensus (i.e. critiquing the narrative), and otherwise aiding teachers' efforts to assert themselves in the education reform debate. Individual teachers' speech, mediated by the internet, affords extension and rejoinder through hyperlinking, quotations, memes, remixes, and caricatures. The teachers' compositions that we examined advance multiple points of view and arguments suggesting an online dialogic collaboration.

Teachers' critical digital compositions assert a stake in the education reform debate, diverging from past reform dialogue structures in which teachers were spoken for by others. We have extended Bakhtin's theory of language to the education reform debate in order to understand its emerging structure and its consequences for teachers as civic actors. In previous work talking with teachers and writing about education reform (Boggs \& Stewart, 2014; Stewart, 2012), we wrestled with representations of teacher voice in an effort to understand their dynamic roles. In the process, a concept of education reform as a socially constructed discourse has coalesced. This concept helps us recognize the dynamic, interpersonal potential of language as a mediating feature of the discourse. It underpins the following principle assertions about education reform:

- Teachers' online compositions revisit and challenge sanctioned narratives, which is a process Bakhtin (1981) framed as bringing authoritative language into live speech to wrest new answers from it in the process of ideological becoming.

- Human struggles are predicted, accomplished, and transformed in, alongside, and through conventionrich forms of speaking. Dissent is possible when people pick up existing speech genres and strategically adapt them.

- The education reform debate gains new voices as teachers seek to muster public support. Teachers' online compositions resonate with popular movements word-wide.

The concept of education reform as a socially constructed discourse helps us understand how the socio-ideological language of education reform, and its corresponding discourse communities may be at once highly stratified and subject to popular challenges and restructuring. The concept connects discourse to social change. Our approach is analogous to Bakhtin's (1984) study of the modern novel: discourses once controlled by a unitary (single author) voice are now sites of struggle among many voices. We are listening to teachers' voices and attempting to weigh the collateral effect of their digital 


\section{Emerging Dialogic Structures in Education Reform \\ Trevor Thomas Stewart, George L. Boggs}

compositions on the education reform debate. Teachers' efforts to shift blame and attack narratives of school failure are features of dynamic dialogue structures that are no longer controlled by interlocking unitary voices. The data presented in this paper suggest that Themed Arguments, Rhetorical Moves, and word choice constitute part of the creative reconstruction of education reform dialogue.

\section{Coda}

Digital media's affordances should not be read as straightforwardly democratic. On the contrary, urban teachers' digital dissent shares bandwidth with messages presenting teacher improvement as the simplistic key to education reform that makes dissent appear futile. To characterize digital media tools as a panacea that guarantees meaningful participation would be missing the point of language as site of social struggle. The overarching questions this study raises pertain to historical and political struggle over teachers' roles in education reform. A deep historical view of education reform counteracts the sway of contemporary crisis narratives. Interrogating the Kerner report (1968) and A Nation at Risk (1983) as source texts for educational crisis thinking strengthens critical awareness of contemporary calls to action, which may mask hasty and simplistic solutions with metaphors that appeal to society's imagination. Taking a long historical view of education reform exposes vulnerabilities of building education reform on the "rocks of stability" (Berliner \& Biddle, 1995, p. 14) of standardized tests and, we would add, the myth of the bad urban teacher. Urban teachers' compositions warrant careful attention because they are actively challenging that myth. Teachers are active and sophisticated curators of institutional histories, and their compositions are historicizing education reform in ways that undermine simplistic fusions of data-driven school reforms and social progress. As we look at teachers' efforts to participate in education reform debates, we see teachers and others destabilizing the manufactured crisis of the now.

\section{References}

Achinstein, B. \& Ogawa, R. T. (2012). New teachers of color and culturally responsive teaching in an era of educational accountability: Caught in a double bind. Journal of Educational Change, 13, 1-39.

Alinsky, S. V. (1971). Rules for radicals: A pragmatic primer for realistic radicals. New York, NY: Random House.

American Federation of Teachers. (2004). History. Retrieved 4/28/2016 from: www.aft.org/about/history.

Anyon, J. (2014). Radical possibilities: Public policy, urban education, and a new social movement. New York, NY: Routledge.

$\mathrm{Au}, \mathrm{W}$. (2011). Teaching under the new Taylorism: high-stakes testing and the standardization of the 21st century curriculum. Journal of Curriculum Studies, 43(1), 25-45.

Bakhtin, M. M. (1981). Discourse in the novel (C. Emerson \& M. Holquist, Trans.) In M. Holquist (Ed.), The dialogic imagination: Four essays by M. M. Bakhtin (pp. 259-422). Austin, TX: University of Texas Press.

Bakhtin, M. M. (1984). Problems of Dostoevsky's poetics (C. Emerson, Trans. \& Ed.). Minneapolis, MN: University of Minnesota Press.

Bakhtin, M. M. (1986). The problem of speech genres. (V. McGee, Trans.), In C. Emerson \& M. Holquist, (Eds.), Speech genres and other late essays (pp. 60-102). Austin, TX: University of Texas Press.

Berliner, D. C. \& Biddle, B. J. (1995). The manufactured crisis: Myths, fraud, and the attack on America's public schools. New York, NY: Addison-Wesley. 


\section{Emerging Dialogic Structures in Education Reform}

Trevor Thomas Stewart, George L. Boggs

Boggs, G. L., \& Stewart, T. T. (2014). Critical digital literacies and the struggle over what's common. In A. Heron-Hruby \& M. Landon-Hays (Eds.), Digital networking for school reform: The online grassroots efforts of parent and teacher activists (pp. 1-13). New York, NY: Palgrave-Macmillan.

Boggs, G. L., \& Stewart, T. T. (in press). Critical digital literacies, educational reform, and urban teachers' right to the city. The SoJo Journal: Educational Foundations and Social Justice Education, 1(2).

Brandt, D. (2014). A rise of writing: Redefining mass literacy. New York, NY: Cambridge University Press.

Carnegie Corporation of New York (May 17, 2007). [Press Release] Teacher quality most important school based factor in boosting school achievement. Retrieved 4/28/2016 from http://carnegie.org/news/press-releases/story/news-action/single/view/teacher-quality-mostimportant-school-based-factor-in-boosting-student-achievement/

DeMatthews, D., \& Mawhinney, H. (2014). Social justice leadership and inclusion: Exploring challenges in an urban disctrict struggling to address inequalities. Education Administration Quarterly, 50(5), 844-881.

Gee. J. P. (2008). Social linguistics and literacies: Ideology in Discourses. (3 ${ }^{\text {rd }}$ ed.).London, UK: Routledge.

Gee. J. P. (2014). Literacy and education. London, UK: Routledge.

Gee. J. P., Hull, G., \& Lankshear, C. (1996). The new work order: Behind the language of the New Capitalism. Boulder, CO: Westview.

Goldstein, D. (2014). The teacher wars: A history of America's most embattled profession. New York, NY: Doubleday.

Graff, H. J. (1979). The literacy myth: Literacy and social structure in the nineteenth century city. New York, NY: Academic Press.

Graff, H. J. (1987). The labyrinths of literacy. London, UK: Falmer.

Hattie, J. (2009). Visible learning: A synthesis of over 800 meta-analysis relating to achievement ( $1^{\text {st }}$ ed.). New York, NY: Routeledge.

Hattie, J. (2011). Visible learning for teachers: Maximizing impact on learning ( $1^{\text {st }}$ ed.). New York, NY: Routledge.

Hymes, D. (1964). Introduction: Toward ethnographies of communication. In J. J. Gumperz and D. Hymes (Eds.), The ethnography of communication (pp. 1-34). Washington, DC: American Anthropological Association.

Jenkins, H., Purushotma, R., Weigel, M., Clinton, K., \& Robison, A. J. (2009). Confronting the challenges of participatory culture: Media education for the $21^{\text {st }}$ Century. Cambridge, MA: MIT Press.

Karp, S. (2012). On point: Real reform happens in the community. [Blogpost]. Virginia Education Association. Retrieved 4/28/2016 from: www.veanea.org/home/1860.htm.

Kohn, A. (2011). Feel-bad education: And other contrarian essays on children and schooling. Boston, MA: Beacon Press.

Heron-Hruby, A., \& Landon-Hays, M. (Eds.). (2014). Digital networking for school reform: The online grassroots efforts of parent and teacher advocates. New York, NY: Palgrave-Pivot.

Leu, D. J., Kinzer, C. K., Coiro, J. L., \& Cammack, D. W. (2004). Toward a theory of new literacies emerging from the Internet and other information and communication technologies. In R. Ruddell 


\section{Emerging Dialogic Structures in Education Reform Trevor Thomas Stewart, George L. Boggs}

and N. Unrau (Eds.). Theoretical models and processes of reading (5 $5^{\text {th }}$ ed.) (pp. 1568-1611). Newark, DE: International Reading Association.

Maxwell, J. A. (2005). Qualitative research design: An interactive approach (2 ${ }^{\text {nd }}$ ed.).Thousand Oaks, CA: Sage.

Moore, R. [Renee Moore /teach Moore] (2009, March 2). This frustrated young teacher sounds like many I have mentored or worked with over the years. They come bright-eyed, eager to do good, and most of them woefully underprepared for the realities of the modern classroom. This teacher mentions majoring [Blog post comment]. Retrieved 4/28/2016 from: http://blogs.edweek.org/teachers/living-in-dialogue/2009/03/an_urban teacher_tells_us why.html

Nichols, S. L. \& Berliner, D. C. (2007). Collateral damage: How high stakes testing corrupts America's schools. Cambridge, MA: Harvard Education Press.

Ravitch, D. (2013). Reign of error: The hoax of the privatization movement and the danger to America's public schools. New York, NY: Alfred A. Knopf.

Rud. A. G. (1993). Breaking the egg crate. Educational Theory, 43(1), 71-83.

Rush, L. S. \& Scherff, L. (2015). Value-added models and why we should all be worried.English Education, 47(3), 195-203.

Saville-Troike, M. (2003). The ethnography of communication. An introduction (3rd ed.). Oxford, UK: Blackwell.

Strauss, V. (2015, February 7). Teacher tells Congress: 'We simply cannot ignore the stunning impact of income inequality and high child poverty'. Washington Post, Retrieved 4/28/2016 from http://www.washingtonpost.com/blogs/answer-sheet/wp/2015/02/07/teacher-tells-congress-wesimply-cannot-ignore-the-stunning-impact-of-income-inequality-and-high-child-poverty/

Stewart, T. T. (2012). English teachers, adminstrators, and dialogue: Transcending the asymmetry of power in the discourse of educational policy. English Education, 44(4), 375-393.

Warren, M. R. (2005). Communities and schools: A new view of urban education reform. Harvard Educational Review, (75)2, 133-173. 


\section{Appendix: Abbreviated presentation of themed arguments with codes}

\begin{tabular}{|c|c|}
\hline Compositions & Codes \\
\hline 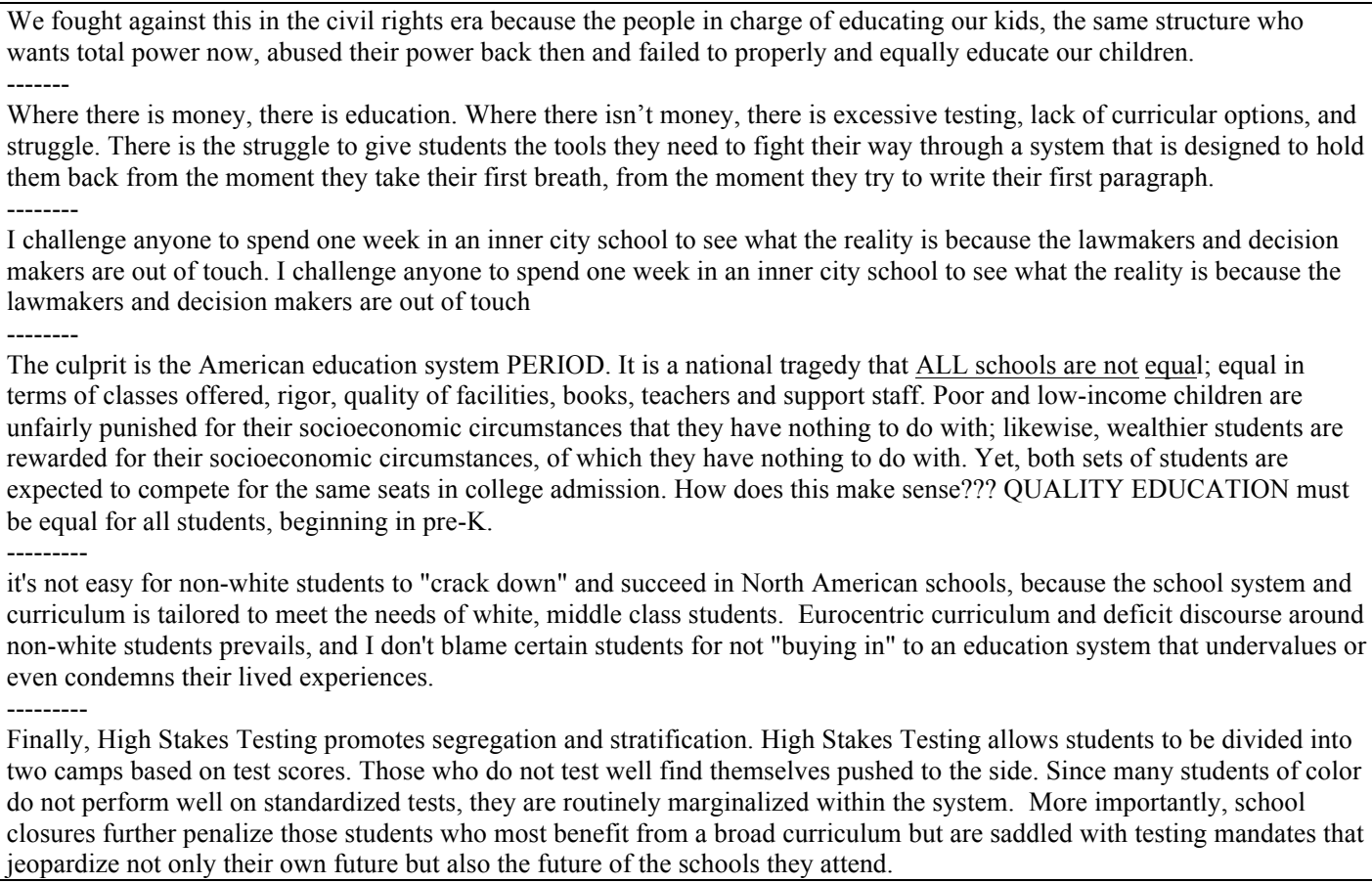 & \\
\hline $\begin{array}{l}\text { So what we have is a political and corporate power structure using federal dollars to gain access and control over our black } \\
\text { and brown children from the time they enter school until they leave. } \\
\text { The point being: Christie, like every other Republican governor, is scamming the middle-\& upper-middle-class taxpayers } \\
\text { with the promise of lowering their taxes by privatizing public education for the poor, while raking in campaign monies from } \\
\text { for-profit education corporations } \\
\text { Now, I'm tired of Bloomberg, Black, Gates, Rhee, Whitney Tilson, etc, who think they know all when they know nothing. I } \\
\text { am grateful that my husband and I can afford for me to make a career change, as I will almost certainly be taking a pay cut. } \\
\text { And I don't care- the next school year will be my last, and I am so done } \\
\text {-------- } \\
\text { these perspectives sound eerily similar to the countless failed "urban renewal" projects done in cities over the past } 60 \text { years - } \\
\text { technocrats wanting to demolish what exists and instill their unproven vision of what is best instead of engaging with the } \\
\text { people who are already there. }\end{array}$ & \\
\hline $\begin{array}{l}\text { If every favorite teacher would disappear tomorrow the whole nation would mourn. If every standardized test disappeared } \\
\text { tomorrow...yeah, not so much } \\
\text { Add into this a standardized test which says every child must acquire the same skills at the same time and you have the } \\
\text { recipe for mediocrity and bias. } \\
\text { A growing number of parents, school boards, teachers and civil rights organizations are beginning to question the fairness of } \\
\text { our overreliance on standardized tests and recently over } 300 \text { groups, including the NAACP Legal Defense Fund signed a } \\
\text { petition to ask congress to ban the use of such tests. } \\
\text { Since } 2001 \text { public education has been the target of education reformers who believe that more testing especially high stakes } \\
\text { testing, and firing teachers based on test scores is what low-income, minority, and special needs children need to succeed. } \\
\text { Teachers are Evaluated Based on Student Test Scores. This is ridiculously inaccurate and unfair. Standardized tests } \\
\text { do NOT effectively measure student learning. They measure family income. So teachers who have richer students have } \\
\text { generally more favorable evaluations than those who teach the poorest and most difficult children. Value-Added Measures, } \\
\text { as these are often called, have been labeled junk science by national statistical organizations. They violate a basic principle } \\
\text { of the field that you cannot use a test designed to evaluate one factor as a way to evaluate an entirely different factor. } \\
\text { Removing due process would make the teachers who serve the most at-risk students, themselves, unfairly at risk of losing } \\
\text { their jobs. }\end{array}$ & \\
\hline
\end{tabular}




\section{Emerging Dialogic Structures in Education Reform}

Trevor Thomas Stewart, George L. Boggs

Teaching in the inner city is an entirely different animal. I've seen teachers injured by first and second graders, cursed at, chased around the room. And this is acceptable, because the children are not receiving the help they need right away, and teachers are not trained or supported to handle these children, and administrators usually don't want to be bothered.

As a teacher, I have seen huge changes in the past 20 years. Kids are having kids and raising them with little or no parenting skills. Those kids are growing up in chaos and they are coming to school not able to think about education...they are too worried about mama's new boyfriend, or drugs, or gangs, or neighborhood violence, or poverty, or a million other aspects of life in the inner city. Who the hell cares about math and reading when you've got the kind of problems most people can't even imagine? Teachers can only do so much. We are constantly trying to learn the best way to teach these kids, and it's tough. They often come from parents who see teachers as the enemy, because they didn't have good experiences in school.

If you've ever tried to work as a teacher in a predominantly minority high school ANYWHERE, in or out of the city, you'd know. It is impossible to teach anybody anything there. Everybody acts like you're committing a crime against humanity by trying to teach math.

What I hear in this story though is a lot of miscommunication or no communication. Not all the students are disruptive; not all the parents show up to fight in public; surely not every administrator in the district is ineffective--so what's the rest of the story?

It is a false idea that the teachers drive the students' learning based solely upon standardized test scores. I have been a Highly Effective teacher in several schools and a very Ineffective teacher in two high schools that have failed for years before I arrived and will continue to fail long after I depart. Districts have tried placing their Highly Qualified and Highly Effective teachers in their lowest performing schools as measured by standardized test scores. It did not work. The students' poor performance on standardized tests are linked more to high absentee rates than teaching abilities. In my district, teachers in the poorest performing schools are now being evaluated on student behavior and attendance. However, the students who fail to come to school have the lowest standardized test scores in the state. It is very difficult to teach someone who does not come to school.

In the U.S., if you can believe it, approximately 1.3 million students were homeless during the 2012-2013 year. How can a child learn if he or she is homeless or hungry? It is time to invest in our kids--who are the future of this country. We don't need huge tax breaks for billionaires and large corporations. We need to end child poverty.

\section{(cc) EY}

New articles in this journal are licensed under a Creative Commons Attribution 4.0 United States License. ULLS

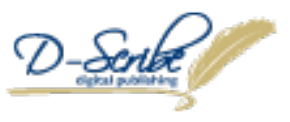

This journal is published by the University Library System, University of Pittsburgh as part of its D-Scribe Digital Publishing Program and is cosponsored by the University of Pittsburgh Press. 